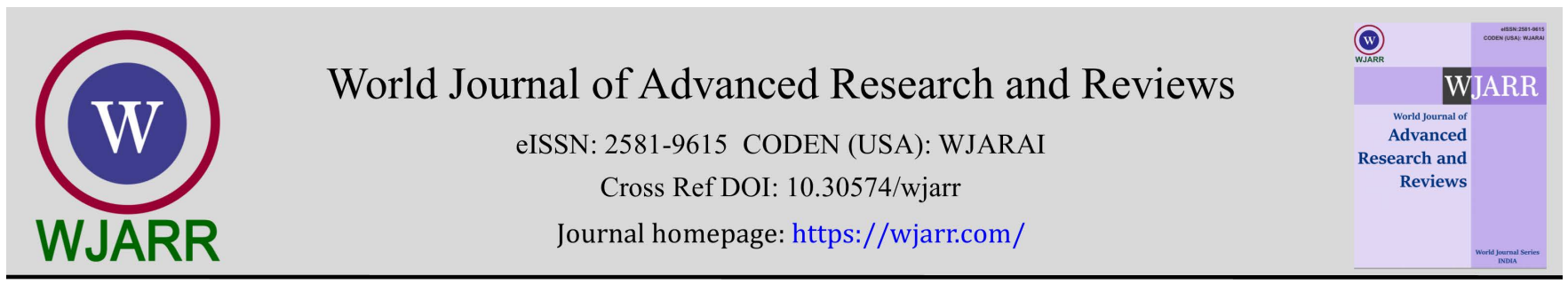

(CASE REPORT)

\title{
COVID-19 infection complicated by priapism
}

\author{
Ilyass Laaribi $1,2,{ }^{*}$ and Mehran Monchi ${ }^{2}$ \\ ${ }^{1}$ Department of Intensive Care Unit, Mohammed VI University Hospital, Oujda, Morocco. \\ ${ }^{2}$ Intensive care unit, Melun Hospital Center, France.
}

World Journal of Advanced Research and Reviews, 2021, 12(03), 072-074

Publication history: Received on 30 October 2021; revised on 02 December 2021; accepted on 04 December 2021

Article DOI: https://doi.org/10.30574/wjarr.2021.12.3.0668

\begin{abstract}
SARS-CoV-2 infections are accompanied by a high incidence of thromboembolic events. The infection is responsible for endothelial injury, with frequent presence of anti-phospholipid antibodies and a pro thrombotic state. All of these manifestations lead to localized thrombosis mainly in the lungs and much more rarely to arterial thrombosis.
\end{abstract}

We report the case of a 67-year-old patient who presented to the emergency room for priapism complicating a Covid19 infection.

Keywords: SARS-CoV-2; Covid-19; Thromboembolic events; Priapism; ARDS

\section{Introduction}

SARS-CoV-2 infection is most commonly manifested by influenza-like illness and respiratory symptoms. Around 5 to $10 \%$ of these patients develop acute respiratory distress syndrome (ARDS) requiring hospitalization [1]. Beyond this respiratory damage, other digestive, neurological and especially thromboembolic damage have been reported [2].

With the spread of the pandemic, it turned out that infection with Covid 19 could be associated with an increased risk of developing thrombotic events including deep vein thrombosis of the lower limbs, pulmonary embolism and also arterial thrombosis. A case of Covid 19 infection complicated by priapism has been described [3], with no established causal link.

We report the case of a 67-year-old patient who came to the emergency room for priapism complicating a Covid-19 infection.

\section{Clinical case}

A 67-year-old patient, obese with a body mass index (BMI) of 35, hypertensive, followed for atrial fibrillation treated with beta-blocker and Coumadin, presented 10 days before his admission a SARS-CoV-2 infection. He developed dyspnea and priapism, prompting his coming to the Emergency Department. On presentation, the temperature was 36.6 ${ }^{\circ} \mathrm{C}$, the heart rate 60 beats per minute, the blood pressure $109 / 77 \mathrm{mmHg}$, the respiratory rate at 26 / minute, and the pulse saturation Sp02 74\% in ambient air and 93\% on non-invasive ventilation at 100\% FiO2. The chest x-ray on admission showed bilateral interstitial syndrome, the thoracic computed tomography showed an involvement of more than $75 \%$ of the pulmonary parenchyma without signs of pulmonary embolism and a transthoracic echocardiography showed a floating thrombus from the vena cava inferior to the border of the right atrium. The biological workup revealed a biological inflammatory syndrome with an INR of 9.

\footnotetext{
* Corresponding author: Ilyass Laaribi

Department of Intensive Care Unit, Mohammed VI University Hospital, Oujda , Morocco.
}

Copyright $(2021$ Author(s) retain the copyright of this article. This article is published under the terms of the Creative Commons Attribution Liscense 4.0. 
The patient was treated with vitamin K, and Dexamethasone IV. A urological opinion was requested, carrying out a placement of a supra pubic catheter in front of a retention of urine, and a puncture of the cavernous bodies with injection of phenylephrine, without regression of priapism. A 2nd cavernous drainage followed by a caverno-cancellous shunt and a posthectomy in the operating room is then performed but without regression of the priapism. An amputation is then considered after the necrosis with draft penile prosthesis.

The patient's respiratory status worsened, he was intubated, ventilated in prone position, and treated with heparin for venous thrombosis, one week after admission, the patient presented with thrombocytopenia of up to $1 \mathrm{G} / \mathrm{L}$ associated with an hemorrhagic syndrome refractory to platelet transfusions; heparin-induced thrombocytopenia was eliminated, The central origin was ruled out and the test for circulating anticoagulant came back negative. In the absence of arguments pointing to disseminated intravascular coagulopathy or thrombotic microangiopathy and the peripheral nature of the thrombocytopenia, the presence of anti-platelet antibodies probably linked to Covid-19 infection has been suspected. The patient underwent 5 sessions of plasmapheresis with complete remission of the thrombocytopenia.

The remainder of the ICU stay was marked by several episodes of Ventilator-associated pneumonia (VAP)and Intensive care unit-acquired weakness. The patient was weaned from mechanical ventilation and extubated one month after admission. He was readdressing to urologists who, in the face of extensive glandular necrosis, performed a glandulectomy and resection of the non-viable corpora cavernosa and a ventral penile urethrostomy.

\section{Discussion}

Patients with Covid-19 are exposed to several known risk factors for VTE such as prolonged bedrest, hypoxemia. In addition, increasing age and obesity, two risk factors for VTE, and which we find in our patient; are also well-definied predictors of the development of a severe form of Covid-19 [4-5]. Observations have been reported of patients with thrombosis even under anticoagulant treatment at least prophylactic [6].

Priapism is defined as an abnormally prolonged partial or complete erection that persists beyond or is unrelated to desire or sexual stimulation [7]. There are 3 different types of priapism: ischemic priapism also known as venous or low flow, being the most common, more than $90 \%$ of cases, characterized by a rigid and painful erection resulting from the absence of venous drainage of the cavernous bodies, which was the case in our patient; and more rarely non-ischemic or high-flow priapism and intermittent priapism [8]. There are various identifiable causes of priapism, however the majority of cases are idiopathic. The other etiologies known of ischemic priapism are hematologic mainly sickle cell disease, medicinal (antipsychotic, antidepressant, anticoagulant, alpha-blocker, intracavernous prostaglandin), toxic (cocaine, marijuana), neoplastic, neurological (spinal cord trauma, brain tumor), scorpion and spider bites and metabolic (gout, amyloidosis, diabetes) [9-10].

Ischemic priapism is a therapeutic emergency to prevent irreversible erectile dysfunction. The duration of priapism and the time to treatment are crucial and condition the prognosis, smooth muscle necrosis sets in after 48 hours [11]. Initially, and if the erection has lasted for less than 24 hours, conservative measures (cooling, analgesics, ejaculation, physical activity) may be offered pending urological treatment. The specialized management consists of a puncture aspiration of the cavernous bodies using a needle after local anesthesia or penile block at the level of the lateral edge of the penis supplemented by an intracavernous injection of alpha-adrenergic agonists such as phenylephrine or etilefrine. In the event of failure of the previous methods or of priapism evolving for more than 48 hours, surgical treatment will be indicated by caverno-spongiosum shunt allowing the venous blood to be drained from the cavernous bodies. Finally, for priapism that has been evolving for more than 48-72 hours, the placement of a penile implant can be discussed either urgently or at a distance from the episode of priapism [12-13].

There is no similar case in the literature associating atypical thrombosis and thrombocytopenia during Covid-19 infection, the only reported cases of this association have been described after vaccination with Covid-19 vaccines and more recently termed "vaccine-induced immune thrombotic thrombocytopenia (VITT)" [14], but the mechanism appears to be different in our patient.

\section{Conclusion}

Priapism is a rare condition, all the more so as a thromboembolic complication of Covid-19, it requires rapid treatment in order to limit the often-irreversible sequelae. 


\section{Compliance with ethical standards}

\section{Acknowledgments}

This research did not receive any funding.

\section{Disclosure of conflict of interest}

The authors declare no conflict of interest.

\section{Statement of informed consent}

Informed consent was obtained from all individual participants included in the study.

\section{References}

[1] Zhu N, Zhang D, Wang W, Li X, Yang B, Song J, Zhao X, Huang B, Shi W, Lu R, Niu P, Zhan F, Ma X, Wang D, Xu W, Wu G, Gao GF, Tan W; China Novel Coronavirus Investigating and Research Team. A Novel Coronavirus from Patients with Pneumonia in China, 2019. N Engl J Med. 2020; 382(8): 727-733.

[2] Gupta A, Madhavan MV, Sehgal K, Nair N, Mahajan S, Sehrawat TS, Bikdeli B, Ahluwalia N, Ausiello JC, Wan EY, Freedberg DE, Kirtane AJ, Parikh SA, Maurer MS, Nordvig AS, Accili D, Bathon JM, Mohan S, Bauer KA, Leon MB, Krumholz HM, Uriel N, Mehra MR, Elkind MSV, Stone GW, Schwartz A, Ho DD, Bilezikian JP, Landry DW. Extrapulmonary manifestations of COVID-19. Nat Med. Jul 2020; 26(7): 1017-1032.

[3] Lamamri M, Chebbi A, Mamane J, Abbad S, Munuzzolini M, Sarfati F, Legriel S. (2021). Priapism in a patient with coronavirus disease 2019 (COVID-19). The American journal of emergency medicine. 2021; 39: 251.e5-251.e7.

[4] Huang C, Wang Y, Li X, Ren L, Zhao J, Hu Y, Zhang L, Fan G, Xu J, Gu X, Cheng Z, Yu T, Xia J, Wei Y, Wu W, Xie X, Yin W, Li H, Liu M, Xiao Y, Gao H, Guo L, Xie J, Wang G, Jiang R, Gao Z, Jin Q, Wang J, Cao B. Clinical features of patients infected with 2019 novel coronavirus in Wuhan, China. Lancet. 15 Feb 2020; 395(10223): 497-506.

[5] Yue H, Bai X, Wang J, Yu Q, Liu W, Pu J, Wang X, Hu J, Xu D, Li X, Kang N, Li L, Lu W, Feng T, Ding L, Li X, Qi X. Gansu Provincial Medical Treatment Expert Group of COVID-19. Clinical characteristics of coronavirus disease 2019 in Gansu province, China. Ann Palliat Med. Jul 2020; 9(4): 1404-1412.

[6] Klok FA, Kruip MJHA, van der Meer NJM, Arbous MS, Gommers DAMPJ, Kant KM, Kaptein FHJ, van Paassen J, Stals MAM, Huisman MV, Endeman H. Incidence of thrombotic complications in critically ill ICU patients with COVID19. Thromb Res. Jul 2020; 191: 145-147.

[7] Broderick GA, Kadioglu A, Bivalacqua TJ, Ghanem H, Nehra A, Shamloul R. Priapism: pathogenesis, epidemiology, and management. J Sex Med. 2010 Jan; 7 (1 Pt 2): 476-500.

[8] Burnett AL. Pathophysiology of priapism: dysregulatory erection physiology thesis. J Urol. 2003 Jul; 170(1): 2634.

[9] Salonia A, Eardley I, Giuliano F, Hatzichristou D, Moncada I, Vardi Y, Wespes E, Hatzimouratidis K; European Association of Urology. European Association of Urology guidelines on priapism. Eur Urol. Feb 2014; 65(2): 4809.

[10] Shigehara K, Namiki M. Clinical Management of Priapism: A Review. World J Mens Health. Apr 2016; $34(1): 1-8$.

[11] Spycher MA, Hauri D. The ultrastructure of the erectile tissue in priapism. J Urol. Jan 1986; $135(1): 142-7$.

[12] Ridgley J, Raison N, Sheikh MI, Dasgupta P, Khan MS, Ahmed K. Ischaemic priapism: A clinical review. Turk J Urol. Mar 2017; 43(1): 1-8.

[13] Bartolucci P, Galactéros F. Clinical management of adult sickle-cell disease. Curr Opin Hematol. May 2012; 19(3): 149-55.

[14] Greinacher A, Thiele T, Warkentin TE, Weisser K, Kyrle PA, Eichinger S. Thrombotic Thrombocytopenia after ChAdOx1 nCov-19 Vaccination. N Engl J Med. 3 Jun 2021; 384(22): 2092-2101. 